\title{
Vestibular Function Evaluation in Endemic Diseases Combat Agents
}

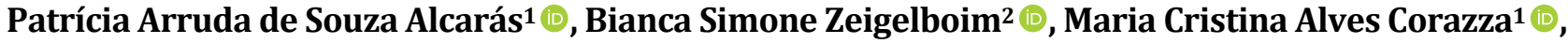 \\ Débora Lüders² (), Jair Mendes Marques² (), Adriana Bender Moreira de Lacerda ${ }^{*}$ (i) \\ ${ }^{1}$ University of Western São Paulo, UNOESTE, Presidente Prudente, São Paulo, Brazil \\ ${ }^{2}$ Tuiuti University of Paraná, UTP, Curitiba, Paraná, Brazil \\ ${ }^{3}$ Université de Montréal, UdeM, Quebec, Canada \\ Email: *adriana.lacerda@umontreal.ca
}

How to cite this paper: de Souza Alcarás, P.A., Zeigelboim, B.S., Corazza, M.C.A., Lüders, D., Marques, J.M. and de Lacerda, A.B.M. (2021) Vestibular Function Evaluation in Endemic Diseases Combat Agents. Health, 13, 144-156.

https://doi.org/10.4236/health.2021.132013

Received: December 10, 2020

Accepted: February 20, 2021

Published: February 23, 2021

Copyright (c) 2021 by author(s) and Scientific Research Publishing Inc. This work is licensed under the Creative Commons Attribution International License (CC BY 4.0).

http://creativecommons.org/licenses/by/4.0/

\begin{abstract}
Introduction: Simultaneous exposure to certain chemical agents and noise may cause synergistic, additive or potentiating effects on the auditory and vestibular system. However, there is still a lack of studies investigating simultaneous exposure to pesticides and noise in the vestibular system. Purpose: To analyze the findings of the vestibular evaluation of endemic diseases combat agents when simultaneously exposed to pesticides and noise. Method: Thirty-three male pesticide-exposed and noise-fighting endemic diseases combat agents participated in the study. The age range was 48 to 67 years (mean $=56$ years). All participants underwent vestibular examinations, such as positional nystagmus research, spontaneous nystagmus with open and closed eyes, semi-spontaneous nystagmus, optokinetic nystagmus, pendular screening, per rotatory, caloric tests and tonal audiometry. Data were analyzed by descriptive statistics. Results: Altered exams were presented in $36.4 \%$ of the cases. There was no statistically significant relationship between pesticide handling time and test results $(\mathrm{p}=0.2825)$. The results of pure tone audiometry correlated significantly ( $\mathrm{p}=0.0494$ ) with the vestibular exams, as participants who presented with worse hearing thresholds at the frequency of $4000 \mathrm{~Hz}$ in the right ear also presented altered results in the vestibular exam. Conclusion: The present study concluded that more than $1 / 3$ of the studied population presented with vestibular dysfunction, which was related to anterior and posterior labyrinth alteration (Cochlear-Vestibular Syndrome). No central vestibular alteration was noted in this population.
\end{abstract}

\section{Keywords}

Community Health Workers, Pesticides, Noise, Hearing, Vestibular System 


\section{Introduction}

The endemic diseases combat agents (EDCA) are professionals who work in public health preventing and fighting diseases present in the environment, such as dengue fever, Chagas' disease, leishmaniasis, and malaria [1]. Their job includes inspecting houses, empty lots, warehouses, and commercial establishments, searching for outbreaks of endemic diseases. They also manipulate and apply larvicides and insecticides to fight vectors and instruct the population regarding the prevention and treatment of infectious diseases [2].

The co-exposure to physical and chemical risks are occupational hazards that must be considered regarding this profession. Authors [3] reported that the EDCA are the health professionals most exposed to pesticides, as they are exposed to it from preparing the solution to applying it. The contamination may be through skin absorption and breathing, especially among the agents that spray the pesticides [4]. However, they are not exposed to pesticides alone, but also to noise from the automatic pump sprayers and heavy ultra-low volume (ULV) sprayers. Although the noise level is reported in a few studies related to pesticide exposure, its assessment is advisable.

Besides the occupational risks related to physical and chemical agents, there are also the ergonomic, social, biological, and accident risks [5]-[12].

Regarding the damages to health, a study pointed out that the main diseases and symptoms reported by the EDCA are the risks of skin cancer, pain from work-related repetitive strain injury and musculoskeletal disorders, as well as the risks of headache and dizziness [13].

Studies have shown damage to the peripheral and central auditory system of populations exposed to pesticides [7] [14]-[25]. However, in most studies, the noise was either not present or its exposure was not considered. In addition, some studies have addressed the effects of pesticides on the vestibular system in humans [15] [26] and in guinea pigs [27] [28].

Hence, this study aimed to evaluate the vestibular functions in endemic diseases combat agents.

\section{Methods}

\subsection{Type and Location of the Study}

This descriptive, prospective, cross-sectional study was conducted at a speech language pathology clinic in southern Brazil.

\subsection{Ethical Issues}

This study was approved by the Research Ethics Committee (REC) of the Worker's Hospital/SES/PR by Plataforma Brasil, protocol number 1.242.014. Please be informed that all ethical precepts have been respected.

The Informed Consent Forms (ICF) were obtained during interviews conducted individually, in a private room, while safeguarding the identity and integrity of each participant. All participants were informed on the objectives and 
procedures of the research, and freely and spontaneously signed the informed consent form, without the burden of participation and with the freedom to withdraw at any time.

\subsection{Study Population}

The selected population was public employees of the State of Paraná who work in campaigns to combat vectors present in the environment.

An invitation was sent by the Syndicate to all public employees of the state. After freely accepting to participate in the study, the employees were sent, on pre-scheduled dates, to a clinic in the south of the country.

Thus, the population sample consisted of 33 male EDCA, aged 48 to 67 years (mean $=56$ years; $\mathrm{SD}=5.3$ ), occupationally exposed to pesticides (organophosphate and pyrethroid insecticides), and noise generated by automatic pesticide sprayers on average for 31.33 years (range of exposure from 20 to 42 years).

Usually, the morning shift with heavy ULV goes from 5:00 a.m. to 8:00 a.m., possibly extending up to 10:00 a.m. The afternoon shift goes from 4:00 p.m. to 8:00 p.m., possibly extending up to 10:00 p.m. Workers are exposed to risk agents for six to 10 hours a day on average, besides the time they take maintaining the equipment preparing the substances.

As for the backpack ULV, the time of exposure can reach eight hours a day, avoiding the intense sun hours. However, according to information from the place that sent the pesticide- and noise-exposed workers, the time of exposure to the risk agents ranged from four to six hours a day.

According to the information provided by the XXX, the equivalent mean level of motorized backpack pumps is $107 \mathrm{dBA} / 4$ hours (Leq decibel in weighting A for four hours), while the vehicle-coupled heavy Ultra Low Volume (ULV) generates a $75 \mathrm{dBA} / 4$ hours noise inside the vehicle with closed windows and 110 $\mathrm{dBA} / 4$ hours outside the vehicle.

In addition to noise exposure, participants reported exposure to organophosphate and pyrethroid pesticides, as well as a history of past exposure to other types of pesticides, such as organochlorines, carbamates, and larvicides.

Regarding the use of personal protective equipment, 27 (82\%) EDCA reported using hearing protectors during work activities. In addition to hearing protectors, workers reported wearing a breathing mask, disposable clothing, hats, boots, waterproof gloves, and goggles. Tasks performed by the agents included pesticide preparation, application, and material cleaning after application. The application of pesticides involved spraying the poison through the backpack pump, hand pump, and tracked vehicles.

\subsection{Procedures}

All the participants were submitted to a vestibular assessment to verify the existence of vestibular disorders and tonal audiometry after an inspection of the external ear canal was conducted with the MD Mark II model otoscope. 
The vestibular function evaluation was performed on a single day in the morning, with groups of 3 to 4 workers per day/evaluated. In total, there were six months for data collection, which is performed every fifteen days, on Fridays, from 7:30 a.m. to 11:00 a.m.

The vestibular function evaluation is composed of many labyrinthine function and ocular tests. The first part of the evaluation was clinical and consisted of a systematic search for spontaneous, gaze, and positional nystagmus (Brandt \& Daroff's maneuver).

We have used the vector electronystagmography (VENG), model VN316 (Berger Eletromedicina Ltda., São Paulo, São Paulo, Brazil), a Ferrante COD 14,200 rotating chair with a rotation of 0.01 to $0.5 \mathrm{~Hz}$, (Ferrante, São Paulo, São Paulo, Brazil), an EV VEC visual stimulator (Neurograff Eletromedicina Ltda., São Paulo, São Paulo, Brazil), and an air NGR 05 caloric stimulator (Neurograff Eletromedicina Ltda., São Paulo, São Paulo, Brazil). The flow rate used was of 5 and $13 \mathrm{~L} / \mathrm{min}$. Next, we conducted the eye and labyrinth VEG tests, according to the criteria proposed by authors [29].

We verified spontaneous and gaze nystagmus, the oscillatory tracking test, optokinetic nystagmus search, and rotatory and caloric tests. Were corded the caloric stimulation time in each ear using air at $42^{\circ} \mathrm{C}$ and $18^{\circ} \mathrm{C}$ for 80 seconds for each temperature, and responses with closed eyes and then with open eyes to observe the inhibitory effect of eye fixation (IEEF). The criteria used in the air caloric test were: absolute value between 2 and 24 degrees/second, with $<2$ degrees/second corresponding to hyporeflexia; and with $>24$ degrees/second corresponding to hyperreflexia; relative values of labyrinth preponderance (LP) < $41 \%$ and nystagmus directional pre-ponderance (NDP) $<36 \%[30]$.

The patterns used to determine vestibular exam findings are presented in Table 1.

In order to determine the hearing threshold of the study participants, all participants underwent tonal audiometry in addition to the vestibular assessment. Tonal audiometry was performed using the Madsen ${ }^{\circledR}$ Itera II audiometer (GN Otometrics S/A Denmark). The device was calibrated. A TDH-39 headset was adopted. The B-71 vibrator was used as needed for bone tonal thresholds.

\subsection{Data Analysis}

Data were statistically analyzed descriptively, using the Fisher-Exact test and the non-parametric Mann-Whitney statistical test, with a significance level of 0.05 (5\%). The prevalence rate and the prevalence ratio were used as needed to verify the occurrence of altered examinations in the population. The prevalence rate was used to verify the occurrence of altered cases. This type of statistical analysis was used because it is a cross-sectional study. Analyses were performed on the BioEstat 5.0.

\section{Results}

Thirty-three (33) EDCA performed the vestibular evaluations; $36.3 \%$ of them 
Table 1. Normal standards and criteria used to analyze the vestibular tests and distinguish central from peripheral.

\begin{tabular}{|c|c|c|c|}
\hline & Normal Vestibular Exam & Peripheral Vestibular Exam & Central Vestibular Exam \\
\hline $\begin{array}{l}\text { Positional } \\
\text { nystagmus } \\
\text { (Brandt \& Daroff's } \\
\text { maneuver) }\end{array}$ & Absent & $\begin{array}{l}\text { Present (rotatory, horizontal rotatory and } \\
\text { oblique) with latency, paroxysm, } \\
\text { weariness, and vertigo }\end{array}$ & $\begin{array}{l}\text { Present (vertical, rotatory, horizontal rotatory, } \\
\text { and oblique), without latency, paroxysm, } \\
\text { weariness, and vertigo }\end{array}$ \\
\hline $\begin{array}{l}\text { Calibration of the } \\
\text { ocular movements }\end{array}$ & Regular & Regular & $\begin{array}{l}\text { Irregular (alterations in latency, accuracy, and } \\
\text { velocity of the saccadic movements) }\end{array}$ \\
\hline $\begin{array}{l}\text { Spontaneous } \\
\text { nystagmus }\end{array}$ & $\begin{array}{l}\text { Present }(<7 \text { degrees/sec) with } \\
\text { closed eyes; absent with open } \\
\text { eyes. }\end{array}$ & $\begin{array}{l}\text { Present ( }>7 \text { degrees/sec) with closed eyes; } \\
\text { absent with open eyes. }\end{array}$ & $\begin{array}{l}\text { Present with open eyes (vertical, rotatory, } \\
\text { horizontal rotatory, oblique, cyclic, dissociated, } \\
\text { and retractor) }\end{array}$ \\
\hline Gaze nystagmus & Absent & Absent & $\begin{array}{l}\text { Present, unidirectional, bidirectional, or mixed; } \\
\text { presents a variety of nystagmus types }\end{array}$ \\
\hline $\begin{array}{l}\text { Oscillatory track } \\
\text { test }\end{array}$ & Types I and II & Type III & $\begin{array}{l}\text { Type IV (pathognomonic); alterations of } \\
\text { morphology and gain }\end{array}$ \\
\hline $\begin{array}{l}\text { Optokinetic } \\
\text { nystagmus test }\end{array}$ & Symmetrical, $<20$ degrees/sec & $\begin{array}{l}\text { Asymmetrical, }>20 \text { degrees/sec, having } \\
\text { superposed spontaneous nystagmus with } \\
\text { open eyes that justifies this alteration }\end{array}$ & $\begin{array}{l}\text { Asymmetrical, }>20 \text { degrees/sec, absent and } \\
\text { reduced }\end{array}$ \\
\hline Rotatory test & $\begin{array}{l}>33 \% \text {, after stimulation of the } \\
\text { lateral and upper semicircular } \\
\text { ducts }\end{array}$ & $\begin{array}{l}>33 \% \text {, after stimulation of the lateral and } \\
\text { upper semicircular ducts }\end{array}$ & $\begin{array}{l}>33 \% \text {, after stimulation of the lateral and upper } \\
\text { semicircular ducts and absence of induced } \\
\text { oblique nystagmus }\end{array}$ \\
\hline Air caloric test & $\begin{array}{l}\text { Absolute value: between } 2 \text { and } \\
24 \text { degrees/sec } \\
\text { Relative values: } \\
\text { Labyrinth preponderance } \\
<41 \% \\
\text { Nystagmus directional } \\
\text { preponderance }<36 \%\end{array}$ & $\begin{array}{l}\text { Absolute value: }<2 \text { degrees } / \mathrm{sec} \\
\text { (hyporeflexia), }>24 \text { degrees/sec } \\
\text { (hyperreflexia) and areflexia } \\
\text { Relative values: } \\
\text { Labyrinth preponderance }>41 \% \\
\text { Nystagmus directional } \\
\text { preponderance }>36 \% \text { (Jongkees formula) }\end{array}$ & $\begin{array}{l}\text { Absolute value: }<2 \text { degrees } / \mathrm{sec} \\
\text { (hyporeflexia), }>24 \text { degrees/sec (hyperreflexia) } \\
\text { and areflexia } \\
\text { Relative values: } \\
\text { Labyrinth preponderance }>41 \% \\
\text { Nystagmus directional preponderance }>36 \% \\
\text { (Jongkees formula). } \\
\text { Different nystagmus types may be observed: } \\
\text { dissociated, inverted, perverted, and absence of } \\
\text { the fast component of the nystagmus }\end{array}$ \\
\hline $\begin{array}{l}\text { Inhibiting effect of } \\
\text { ocular fixation }\end{array}$ & Present & Present & Absent \\
\hline
\end{tabular}

Source: Authors [29] [30].

had alterations in the exams, of which $5(15.2 \%)$ presented with right peripheral vestibular deficit dysfunction and 4 (12.1\%) with left peripheral vestibular deficit dysfunction. Irritative peripheral vestibular dysfunction was observed in $9 \%$ of the cases (Figure 1). Statistical analysis revealed $\mathrm{p}=12 / 33=0.364$, demonstrating prevalence rate of altered results.

The ages of EDCA were separated into three age groups: up to 50 years old, from 51 to 60 years old, and over 60 years old. The proportion of normal cases is higher (75\%), with $25 \%$ being the proportion of altered cases (up to 50 years). Among agents aged between 51 and 60 years, the proportion of normal cases dropped to $70 \%$ and that of altered cases increased to $30 \%$. Among agents over the age of 60 , the proportion of normal cases was very low (20\%), while the proportion of altered cases increased to $80 \%$. When correlating the results of vestibular exams with the age of the participants, Fisher's exact statistical test 


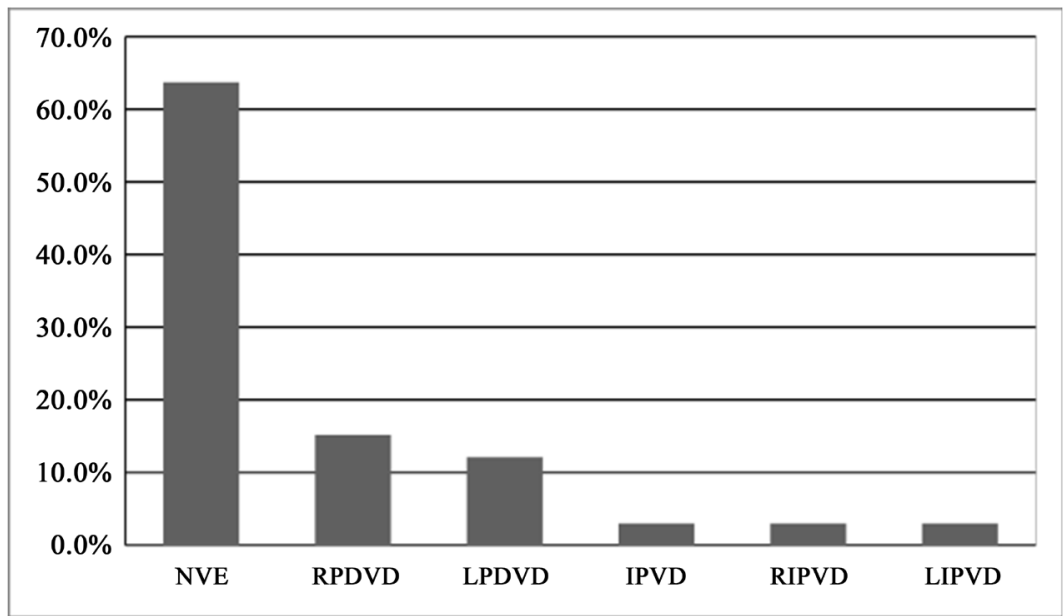

Legend: NVE = normal vestibular exam; RPDVD = right peripheral deficit vestibular dysfunction; LPDVD = left peripheral deficit vestibular dysfunction; IPVD = irritative peripheral vestibular dysfunction; RIPVD = right irritative peripheral vestibular dysfunction; LIPVD = left irritative peripheral vestibular dysfunction.

Figure 1. Vestibular examination result $(\mathrm{N}=33)$.

showed no relationship, since the $\mathrm{p}$-value $=0.1132$.

The results show of the vestibular evaluations took into account the handling time of the pesticide. A higher proportion of normal cases (70\%) among participants with shorter exposure time (up to 30 years) was noted, however, when comparing the exposure time to pesticides, up to 30 years and with more than 30 years of exposure, the Fisher's Exact test showed that the result was not significant at a significance level $(\mathrm{p}=0.2825)$.

The following researchers showed no changes: positional nystagmus, eye movement calibration, spontaneous open-eyed and gaze nystagmus, pendular tracking test, optokinetic and post-rotational nystagmus. Observed changes occurred in the spontaneous closed eyes nystagmus research and in the caloric test. Twelve individuals (36.3\%) presented with peripheral vestibular dysfunctions, nine cases with deficitary peripheral vestibular dysfunction (27.3\%), and three cases (9\%) with irritative peripheral vestibular dysfunction. The vestibular examination was normal in 21 cases (63.7\%).

Nystagmus was observed in seven participants in the spontaneous closed eyes nystagmus study. The prevalence rate of spontaneous closed eyes nystagmus was $21.2 \%$ and the prevalence ratio was 2.3 ; hence, the presence of spontaneous closed eyes nystagmus among participants who presented alterations in the vestibular evaluations was twice as high as among participants who presented no alterations. However, through Fisher's Exact test, there was no statistically significant relationship between the altered tests and the spontaneous closed eyes nystagmus results $(\mathrm{p}=0.1970)$.

Figure 2 shows the auditory and vestibular complaints presented by the study participants. It is noted that $30.3 \%$ of participants complained of tinnitus and dizziness, and $33.3 \%$ complained of hypoacusis. 


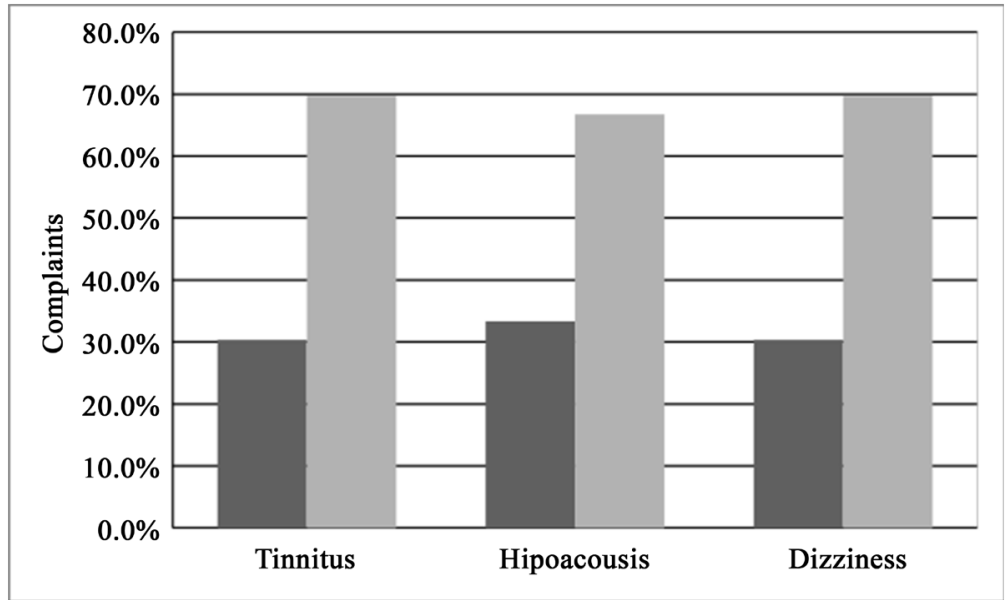

Figure 2. Sample distribution according to complaints $(\mathrm{N}=33)$.

Table 2. Relationship between vestibular examination result and complaint $(\mathrm{N}=33)$.

\begin{tabular}{ccccccc}
\hline & \multicolumn{2}{c}{ Tinnitus } & \multicolumn{2}{c}{ Hipoacousis } & \multicolumn{2}{c}{ Dizziness } \\
\cline { 2 - 7 } Results & Yes & No & Yes & No & Yes & No \\
& $\mathbf{n}(\%)$ & $\mathbf{n}(\%)$ & $\mathbf{n}(\%)$ & $\mathbf{n}(\%)$ & $\mathbf{n}(\%)$ & $\mathbf{n}(\%)$ \\
\hline NVE & $6(60.0)$ & $15(65.3)$ & $8(72.7)$ & $13(59.1)$ & $6(60.0)$ & $15(65.3)$ \\
RPDVD & $1(10.0)$ & $4(17.4)$ & $1(9.1)$ & $4(18.3)$ & $3(30.0)$ & $2(8.7)$ \\
LPDVD & $2(20.0)$ & $2(8.7)$ & $1(9.1)$ & $3(13.6)$ & - & $4(17.4)$ \\
IPVD & $1(10.0)$ & - & $1(9.1)$ & - & $1(10.0)$ & - \\
RIPVD & - & $1(4.3)$ & - & $1(4.5)$ & - & $1(4.3)$ \\
LIPVD & - & $1(4.3)$ & - & $1(4.5)$ & - & $1(4.3)$ \\
Overall & $10(100)$ & $23(100)$ & $11(100)$ & $22(100)$ & $10(100)$ & $23(100)$ \\
p-value & \multicolumn{2}{c}{0.5366} & \multicolumn{2}{c}{0.3522} & & 0.5366 \\
\hline
\end{tabular}

Legend: $\mathrm{NVE}=$ normal vestibular exam; RPDVD = right peripheral deficit vestibular dysfunction; LPDVD

$=$ left peripheral deficit vestibular dysfunction; IPVD = irritative peripheral vestibular dysfunction; RIPVD

$=$ right irritative peripheral vestibular dysfunction; LIPVD $=$ left irritative peripheral vestibular dysfunction.

Fisher's Exact test, at a significance level of 0.05 (5\%), revealed no significant relationship between the vestibular examination results and the complaints, when the two were compared (Table 2).

Table 3 shows the results obtained in pure tone audiometry with the results obtained in the vestibular exams. The Mann-Whitney non-parametric test, at a significance level of $5 \%(0.05)$, showed a significant difference between the thresholds for the right ear at the frequency of $4000 \mathrm{~Hz}(\mathrm{p}=0.0494)$. Therefore, the participants who presented worse hearing thresholds in the right ear at the frequency of $4000 \mathrm{~Hz}$ also presented altered results in the vestibular examinations.

\section{Discussion}

The vestibular evaluation findings showed alterations in the exams in $36.3 \%$ of the endemic diseases combat agents. Among the participants, $15.2 \%$ had exams 
Table 3. Relationship of conventional audiometry with vestibular examination results (N $=33)$.

\begin{tabular}{|c|c|c|c|c|c|}
\hline \multirow{2}{*}{$\begin{array}{c}\text { Ear and frequence } \\
(\mathrm{Hz})\end{array}$} & \multicolumn{2}{|c|}{ NVE } & \multicolumn{2}{|c|}{ AVE } & \multirow{2}{*}{ p-value } \\
\hline & $\mathrm{N}$ & Median & $\mathrm{N}$ & Median & \\
\hline RE250 & 21 & 15.0 & 12 & 15.0 & 0.7363 \\
\hline RE500 & 21 & 10.0 & 12 & 12.5 & 0.1117 \\
\hline RE1000 & 21 & 10.0 & 12 & 15.0 & 0.0516 \\
\hline RE2000 & 21 & 10.0 & 12 & 15.0 & 0.0588 \\
\hline RE3000 & 21 & 15.0 & 12 & 27.5 & 0.1249 \\
\hline RE4000 & 21 & 20.0 & 12 & 35.0 & ${ }^{*} 0.0494$ \\
\hline RE6000 & 21 & 20.0 & 12 & 35.0 & 0.0996 \\
\hline RE8000 & 21 & 25.0 & 12 & 35.0 & 0.0588 \\
\hline LE250 & 21 & 15.0 & 12 & 12.5 & 0.6266 \\
\hline LE500 & 21 & 15.0 & 12 & 10.0 & 0.4542 \\
\hline LE1000 & 21 & 10.0 & 12 & 10.0 & 0.8958 \\
\hline LE2000 & 21 & 10.0 & 12 & 15.0 & 0.3213 \\
\hline LE3000 & 21 & 15.0 & 12 & 25.0 & 0.5125 \\
\hline LE4000 & 21 & 25.0 & 12 & 37.5 & 0.3399 \\
\hline LE6000 & 21 & 40.0 & 12 & 37.5 & 0.3998 \\
\hline LE8000 & 21 & 35.0 & 12 & 42.5 & 0.3592 \\
\hline
\end{tabular}

Legend: $\mathrm{RE}=$ right ear; $\mathrm{LE}=$ left ear; $\mathrm{NVE}=$ normal vestibular exam; AVE = altered vestibular exam. Non-parametric Test Mann-Whitney ( $\mathrm{p}=$ value significant $\left.{ }^{*}\right)$.

suggestive of right deficitary peripheral vestibular dysfunction and $12.1 \%$ suggestive of left deficitary peripheral vestibular dysfunction. Irritative peripheral vestibular dysfunction was observed in $9 \%$ of the cases. These findings point to the fact that all exam deficits due to vestibular dysfunction were peripheral.

Peripheral vestibular dysfunction is characterized by changes in normal patterns and the absence of signs of dysfunction indicating a central lesion. Deficitary peripheral vestibular dysfunctions are correlated with vestibular alterations where there is a total or partial decrease in vestibular function, and generally have a worse prognosis compared to irritative peripheral vestibular dysfunctions [31].

The results did not show alterations in the positional nystagmus, eye movement calibration, spontaneous and gaze nystagmus, pendular tracking test, optokinetic and rotational nystagmus. However, the alterations were observed in the caloric test and the survey of spontaneous closed eyes nystagmus. Alterations in the caloric test were observed in a study with populations exposed to pesticides, as well as in the research of positional nystagmus and/or vertigo [15]. The result of this last test was not observed in the present study.

Some authors report that the only vestibular test that evaluates each maze is ca- 
loric, being a valuable resource for otoneurological diagnosis [32]. It consists of the stimulation of the external ear canal by introducing hot/cold air/water, which heats and cools the lateral semicircular canal wall, generating endolymph convection currents and promoting deviation of the stimulated semicircular canal dome.

All participants presented only with alternations in the spontaneous closed-eye nystagmus, with no alterations in the spontaneous open-eye nystagmus and the gaze nystagmus. This indicated that none presented central alteration. In the spontaneous closed-eye nystagmus survey, 7 participants presented with the same, 3 presented with a normal vestibular exam, and 4 with alteration in vestibular exams. The presence of spontaneous closed-eye nystagmus can be observed in healthy individuals. Spontaneous closed-eye nystagmus in healthy individuals can be considered normal if the result of the slow component angular velocity (SCAV) does not exceed $7 \%$ [29] [30]. Only one participant presented SCAV above $7^{\circ} / \mathrm{s}$, whose right horizontal spontaneous closed-eye nystagmus result associated with the caloric test result (right labyrinthine predominance 9\%) showed irritative peripheral vestibular dysfunction.

In a study, irritative peripheral vestibular dysfunction was observed in $88.8 \%$ of 18 rural workers exposed to organophosphate insecticide-type pesticides [15]. A study showed the population exposed to various types of pesticides with varying degrees of toxicity, such as Manzate (54.2\%), which has toxicology grade III, Folidol (33.3\%), Tamaron (27.1\%), and Gramaxone (25\%), that has a type I toxicology degree and considered highly toxic. Most of the studied population was female (72.2\%) and with a mean age of 36.6 years (range 16 to 59 years old). In addition, it was not mentioned in the study whether this population had combined exposure to noise [15]. This did not corroborate the findings of the present study, considering that among participants who presented vestibular dysfunction, the deficitary type was more evident (27.4\%).

The present study showed no significant relationship between exposure to pesticides and noise and the occurrence of altered vestibular examinations.

Regarding auditory and vestibular complaints, $30.3 \%$ of the participants in the present study presented tinnitus and dizziness and 33.3\% complained of hypoacusis. Tinnitus complaint was observed in other studies with populations exposed to pesticides and noise [17] [19] [23] [33].

A study revealed $57 \%$ of participants to have tinnitus [33]. One study showed a similar occurrence of tinnitus (52.08\%) [17]. Another study found that $28.05 \%$ of workers simultaneously exposed to pesticides and noise complained of tinnitus, increasing this incidence among workers who presented alterations in the audiometry $(60.87 \%)$ [19]. The occurrence of tinnitus in another study reported an incidence of $46 \%$ among agricultural workers [23].

Studies have shown that dizziness complaint is a recurrent clinical symptom in populations exposed to pesticides [15] [34].

Dizziness is characterized by a sensation of alteration in body balance, either rotatory (vertigo) or non-rotatory (body instability), and it appears when there is 
interference in the normal functioning of the body balance system, which may be of peripheral or central origin [35].

Authors have reported that long-term exposure to pesticides may affect the central processing of sensory information for body balance as well as the sensory and somatosensory/vestibular systems [34].

In the present study, no statistically significant relationship was observed between the dizziness complaint and the vestibular exams $(\mathrm{p}=0.5366)$. The dizziness complaint presented by the study participants could not be attributed to the altered vestibular exams. However, it is undisputed that exposure to chemical agents may affect the postural balance of exposed populations [34] [36], and that the age factor may contribute to the increase in dizziness [37] [38].

A statistically significant difference was noted between the auditory pure tone thresholds of the right ear obtained at $4000 \mathrm{~Hz}$ and the results of the altered vestibular exams. This finding may be justified by the anterior and posterior labyrinth intertwined from an anatomo-physiological stand-point, consistent with Cochlear-Vestibular Syndrome. This known fact in the literature justifies the importance of researching the integrity of the auditory system through the auditory exams along with the vestibular exams [39].

In a study, hearing normality was verified by conventional audiological evaluation, among $61.14 \%$ of 18 rural workers exposed to organophosphate insecticides. While $38.8 \%$ presented hearing alterations, $22.22 \%$ of the workers presented hearing loss at the frequencies of 6000 and $8000 \mathrm{~Hz}$, and $16.67 \%$ presented sensorineural hearing loss [15].

\subsection{Study Limitations}

This study presents with typical limitations of a cross-sectional study. It is not possible to conclude a causal relationship, but only the risk of the professional category for vestibular dysfunction. The EDCA, exposed to pesticides and noise, may have other inherent variables, such as age and chronic diseases, that may make them more susceptible to vestibular dysfunction.

\subsection{Study Results' Recommendations from This Study}

The present study showed vestibular changes in EDCA. Further studies are needed to evaluate the possible effects of pesticides and noise on the vestibular system in exposed populations, as there is a lack of studies addressing this problem. Future studies should consider a longitudinal (case/control) design to better characterize the association between pesticide exposure and noise, especially in younger workers. The correlation of vestibular examinations with biological markers is also necessary in order to verify biochemical, immunological, and hematological parameters.

\section{Conclusion}

The occurrence of vestibular dysfunction was observed in more than $1 / 3$ of the 
studied population and related to anterior and posterior labyrinth alteration (Cochlear-Vestibular Syndrome). There was no sign of central vestibular alteration in any of the participants. The most common peripheral alteration was of the deficit type, revealing the chronicity of the condition.

\section{Conflicts of Interest}

The authors declare no conflicts of interest regarding the publication of this paper.

\section{References}

[1] Carneiro, F.F., Rigotto, R.M., Augusto, L.G.S., Friedrich, K. and Búrigo, A.C. (Orgs) (2015) Dossiê ABRASCO: Um alerta sobre os impactos dos agrotóxicos na saúde. Escola Politécnica de Saúde Joaquim Venâncio, Expressão Popular, Rio de Janeiro, São Paulo.

[2] Torres, R. (2009) Agente de combate a endemias. Revista Poli-Saúde, Educação e Trabalho, 3, 16-17.

[3] Lima, E.P., Lopes, S.M.B., Amorin, M.I.M., Araújo, L.H.S., Neves, K.T. and Maia, E.R. (2009) Pesticide Exposure and Its Repercussion in the Health of Sanitary Agents in the State of Ceará, Brazil. Ciência \& Saúde Coletiva, 14, 2221-2230. https://doi.org/10.1590/S1413-81232009000600031

[4] Occupational Safety and Health Administration (2018) OSHA News Releases 2018. https://www.osha.gov/news/newsreleases/infodate-y/2018

[5] Morata, T.C. and Little, M.B. (2002) Suggested Guidelines for Studying the Combined Effects of Occupational Exposure to Noise and Chemicals on Hearing. Noise \& Health, 4, 73-87.

[6] Buchanan, L.H. (2002) Auditory Effects of Occupational/Environmental Lead Exposure. In: Best Practices Workshop: Combined Effects of Chemicals and Noise on Hearing, National Institute for Occupational Safety and Health and the National Hearing Conservation Association, Cincinnati, 21-22.

[7] Johnson, A.C. and Morata, T.C. (2010) Occupational Exposure to Chemicals and Hearing Impairment. In: Torén, K., Eds., Arbet och Hälsa, Vol. 44, University of Gothenburg, Gothenburg, 110.

[8] Campo, P., Morata, T.C. and Hong, O. (2013) Chemical Exposure and Hearing Loss. Disease-a-Month, 59, 119-138. https://doi.org/10.1016/j.disamonth.2013.01.003

[9] Morata, T.C. and Lacerda, A.B.M. (2013) Saúde auditiva. In: Zeigelboim, B.S. and Jurkiewicz, A.L., Eds., Multidisciplinaridade na Otoneurologia, Roca, São Paulo, 386-399.

[10] SESA/PR (2013) Protocolo de avaliação das intoxicações crônicas por agrotóxicos, Superintendência de Vigilância em Saúde, Curitiba.

http://www.abrasco.org.br/UserFiles/Image/PDF\%20protocolo\%20avaliacao\%20int oxicacao\%20agrotoxico.pdf

[11] Alcarás, P.A.S., Lacerda, A.B.M. and Marques, J.M. (2013) Estudo das emissões otoacústicas evocadas e efeito de supressão em trabalhadores expostos a agrotóxicos e ruído. CoDAS, 25, 527-533.

[12] Lacerda, A.B.M., Lobato, D. and Alcarás, P.A.S. (2019) Avaliação audiológica para trabalhadores expostos a agentes químicos com ênfase nos pesticidas. In: Lopes, 
A.C., Gonçalves, C.G.O. and Andrade, W.T., Eds., Fonoaudiologia e saúde auditiva do trabalhador, Book Toy, Ribeirão Preto, 133-157.

[13] Ferreira Júnior, A.R., Torres, A.R.A. and Silva, C.M.A. (2015) Condições laborais dos agentes de combate a endemias e seus efeitos à saúde. Essencial Sobral, 16, 77-95.

[14] Delgado, I.F. and Paumgartten, F.J.R. (2004) Intoxicação e uso de pesticidas por agricultores do Município de Paty do Alferes, Rio de Janeiro, Brasil. Cadernos de Saúde Pública, 20, 180-186. https://doi.org/10.1590/S0102-311X2004000100034

[15] Hoshino, A.C.H., Pacheco-Ferreira, H., Taguchi, C.K., Tomita, S. and Miranda, M.F. (2008) Ototoxicity Study in Workers Exposed to Organophosphate. Revista Brasileira de Otorrinolaringologia, 74, 912-918. https://doi.org/10.1590/S0034-72992008000600015

[16] Körbes, D., Silveira, A.F., Hyppolito, M.A. and Munaro, G. (2010) Alterações no sistema vestibulococlear decorrentes da exposição ao agrotóxico: Uma revisão de literatura. Revista da Sociedade Brasileira de Fonoaudiologia, 15, 146-152. https://doi.org/10.1590/S1516-80342010000100024

[17] Guida, H.L., Morini, R.G. and Cardoso, A.C. (2010) Audiological Evaluation in Workers Exposed to Noise and Pesticide. Brazilian Journal of Otorhinolaryngology, 76, 423-427. https://doi.org/10.1590/S1808-86942010000400003

[18] Jayasingue, S.S. and Pathirana, K.D. (2011) Effect of Deliberate Ingestion of Organophosphate or Paraquat on Brain Stem Auditory-Evoked Potential. Journal of Medical Toxicology, 7, 277-280. https://doi.org/10.1007/s13181-011-0173-3

[19] Delecrode, C.R., Freitas, T.D., Frizzo, A.C.F. and Cardoso, A.C.V. (2012) Prevalence of Tinnitus in Workers Exposed to Noise and Organophosphate. International Archives of Otorhinolaryngologyl, 16, 328-334. https://doi.org/10.7162/S1809-97772012000300005

[20] Kós, M.I., Hoshino, A.C., Asmus, C.I.F., Mendonça, R. and Meyer, A. (2013) Efeitos da exposição a agrotóxicos sobre o sistema auditivo periférico e central: Uma revisão sistemática. Cadernos de Saúde Pública, 29, 1491-1506. https://doi.org/10.1590/S0102-311X2013001200003

[21] Gatto, M.P., Fioretti, M., Fabrizi, G., Gherardi, M., Strafella, E. and Santarelli, L. (2014) Effects of Potential Neurotoxic Pesticides on Hearing Loss: A Review. NeuroToxicology, 42, 24-32. https://doi.org/10.1016/j.neuro.2014.03.009

[22] Judai, M.A. (2015) Estudo dos limiares auditivos em frequências convencionais e altas frequências de moradores e trabalhadores expostos a praguicidas na região do Pontal do Paranapanema. Ph.D. Dissertation, Universidade do Oeste Paulista, Presidente Prudente.

[23] Lobato, D.C.B. (2015) Disfunção auditiva induzida por agrotóxicos em trabalhadores agrícolas do Paraná. Ph.D. Thesis, Universidade Tuiuti do Paraná, Curitiba.

[24] Tomiazzi, J.S. (2017) Avaliação auditiva e citogenética de trabalhadores rurais do Pontal do Paranapanema-SP expostos a agroquímicos e tabagismo, isolado ou combinado. Ph.D. Dissertation, Universidade do Oeste Paulista, Presidente Prudente.

[25] Sena, T.R.R., Dourado, S.S.F., Lima, L.V. and Antoniolli, A.R. (2018) The Hearing of Rural Workers Exposed to Noise and Pesticides. Noise Health, 20, 23-26.

[26] Dick, R.B., Steenland, K., Krieg Jr., E.F. and Hines, C.J. (2001) Evaluation of Acute Sensory-Motor Effetcs and Test Sensitivity Using Termiticide Workers Exposed to Chlorpyrifos. Neurotoxicology and Teratology, 23, 381-393. 
https://doi.org/10.1016/S0892-0362(01)00143-X

[27] Cogo, L.A., Murashima, A.A.B., Santos Filha, V.A.V., Hyppolito, M.A. and Silveira, A.F. (2014) Avaliação funcional do sistema vestibular de cobaias intoxicadas por meio da prova calórica. Revista CEFAC, 16, 1434-1442.

https://doi.org/10.1590/1982-021620149313

[28] Cogo, L.A., Santos Filha, V.A.V., Murashima, A.A.B., Hyppolito, M.A. and Silveira, A.F. (2016) Morphological Analysis of the Vestibular System of Guinea Pigs Poisoned by Organophosphate. Brazilian Journal of Otorhinolaryngology, 82, 11-16. https://doi.org/10.1016/j.bjorl.2015.10.001

[29] Mangabeira-Albernaz, P.L., Ganança, M.M. and Pontes, P.A.L. (1976) Operational Model of the Vestibular Apparatus. In: Mangabeira-Albernaz, P.L. and Ganança, M.M. Ed., Vertigem, Moderna, São Paulo, 29-36.

[30] Costa, K.C.F., Silva, S.M.R. and Ganança, C.F. (2005) Study of Oculomotor and Vestibular Tests Using Digital Vectonystagmography. Disturb. Comun, 17, 315-322.

[31] Palatas, O.H.G., Ganança, C.F. and Ganança, F.F. (2009) Quality of Life of Individuals Submitted to Vestibular Rehabilitation. Brazilian Journal of Otorhinolaryngology, 75, 387-394. https://doi.org/10.1590/S1808-86942009000300014

[32] Arlien-Soborg, P., Zilstorff, K., Grandjean, B. and Pedersen, L.M. (1981) Vestibular Dysfunction in Occupational Chronic Solvent Intoxication. Clinical Otolaryngology \& Allied Sciences, 6, 285-290. https://doi.org/10.1111/j.1365-2273.1981.tb01549.x

[33] Manjabosco, C.W., Morata, T.C. and Marques, J.M. (2004) Perfil Audiométrico de trabalhadores agrícolas. Arquivos Internacionais de Otorrinolaringologia, 8, 285-295.

[34] Sunwook, K., Nussbaum, M.A., Quandt, S.A., Laurienti, P.J. and Arcury, T.A. (2016) Effects of Lifetime Occupational Pesticide Exposure on Postural Control among Farmworkers and Non-Farmworkers. Journal of Occupational and Environmental Medicine, 58, 133-139. https://doi.org/10.1097/JOM.0000000000000655

[35] Zanardini, F.H., Zeigelboim, B.S., Jurkiewics, A.L., Marques, J.M. and Martins-Bassetto, J. (2007) Reabilitação vestibular em idosos com tontura. Pró-Fono Revista de Atualização Científica, 19, 177-184. https://doi.org/10.1590/S0104-56872007000200006

[36] Kamel, F., Rowland, A.S., Park, L.P., Anger, W.K., Baird, D.D., Gladen, B.C., Moreno, T., Stallone, L. and Sandler, D.P. (2003) Neurobehavioral Performance and Work Experience in Florida Farmworkers. Environmental Health Perspectives, 111, 1765-1772. https://doi.org/10.1289/ehp.6341

[37] Tavares, F.S., Santos, M.F.C. and Knobel, K.A.B. (2008) Reabilitação vestibular em um hospital universitário. Revista Brasileira de Otorrinolaringologia, 74, 241-247. https://doi.org/10.1590/S0034-72992008000200014

[38] Zeigelboim, B.S., Klagenberg, K.F., Rosa, M.R.D., Paulin, F., Jurkiewicz, A.L. and Marques, J.M. (2008) Achados vestibulares na população idosa. Fisioterapia em Movimento, 21, 89-99.

[39] Lourenço, E.A., Lopes, K.C., Pontes-JR, A., Oliveira, M.H., Umemura, A. and Vargas, A.L. (2005) Distribution of Neurotological Findings in Patients with Cochleovestibular Dysfunction. Brazilian Journal of Otorhinolaryngology, 71, 288-296. https://doi.org/10.1016/S1808-8694(15)31325-2 